\title{
Pain relief in labour: tramadol versus pentazocine
}

\author{
Kavita Chandnani*, H. B. Sainee
}

Department of Obstetrics and Gynecology, SBKS Medical Institute and Research Centre, Piparia, Vadodara, Gujarat, India

Received: 12 March 2013

Revised: 10 April 2013

Accepted: 14 April 2013

*Correspondence:

Dr. Kavita Chandnani,

E-mail: kavyawch@rediffmail.com

(C) 2013 Chandnani K et al. This is an open-access article distributed under the terms of the Creative Commons Attribution License, which permits unrestricted use, distribution, and reproduction in any medium, provided the original work is properly cited.

\section{ABSTRACT}

Background: The present study was undertaken to compare the effect of $100 \mathrm{mg}$ intramuscular tramadol to $30 \mathrm{mg}$ intramuscular Pentazocine for labour analgesia.

Methods: A total of 60 cases with 37-40 weeks pregnancy in labour, without any foetal or maternal complications were selected. Out of them Inj. Tramadol was given to 30 cases while rest of the 30 patients received injection Pentazocine.

Results: In Tramadol group pain relief was observed in $80 \%$ cases, effect started as early as 7-8 min and continued for 2.13 hrs. While in Pentazocine group pain relief was observed in only 60\% cases with delayed onset (15-16 min), effect lasted for $2.67 \mathrm{hrs}$. Maternal and foetal complications were slightly more in Pentazocine group.

Conclusions: Tramadol is an effective and safe labour analgesic, producing moderate to satisfactory. Besides it also significantly shortens the duration of labour.

Keywords: Tramadol, Pentazocine, Labour analgesia, Pain

\section{INTRODUCTION}

Motherhood though rewarding seems to require sacrifice on part of the women, i.e. to bear the extremely painful process of child birth. This pain if not adequately controlled can lead to maternal and fetal sequelae because of widespread maternal sympathetic activation that causes increase in cardiac output, Blood Pressure and pulse rate of the mother. Effective analgesia prevents the pain included hyperventilation and hypocapnia which can be severe enough to produce tetany in painful labour. Painful labour also reduces uteroplacental blood flow by upto $25 \%$. The requirements of a satisfactory analgesic in labour are safety and effective analgesia throughout the painful periods of labour with no unpleasant maternal side effects and no depressant effects on the baby or on the maternal cardiorespiratory system. ${ }^{8}$ To overcome this problem a number of pharmacological agents have been tried.
Tramadol, a certainly acting drug with low affinity for opioid receptors and pentazocine a weak antagonist and potent agonist for opioid receptors are currently being studied in out department for relief of labour pain. Progress of labour, foetal outcome and side effects were compared in both the groups.

\section{METHODS}

Present study was conducted in the department of Obstetrics and Gynecology, Dhiraj Hospital, S.B.K.S. MIRC, Piparia, Vadodara, Gujarat.

This series included 60 cases out of which 30 cases were treated with tramadol and in remaining 30 cases injection pentazocine was given.

Both primi and multigravida with 37 to 42 weeks pregnancy with vertex presentation in established labour, 
i.e., effective uterine contractions, good cervical effacement and cervical dilatation not less than $3 \mathrm{~cm}$. were included in the study.

Patients with previous uterine scar, malpresentation, multiple presentations, absent membranes, antepartum haemorrhage, cephalopelvic disproportion, pre eclamptic toxemia and other medical and psychiatric diseases were excluded.

In well selected cases, a general and systemic examination was undertaken. Obstetric examinations, inclusive of abdominal and per vaginal examination were performed and informed consent was taken. All cases were done in consultation with anaesthetist and paediatrician.

In tramadol group, Inj. Tramadol $100 \mathrm{mg}$ was given by deep intramuscular injection in upper and outer quadrant of gluteal region with $2 \mathrm{ml}$ syringe. While in pentazocine group, Inj. Pentazocine $30 \mathrm{mg}$ was given by deep intramuscular injection in the gluteal region.

Active labour was defined as dilatation of cervix $>3 \mathrm{~cm}$ with one uterine contraction every $3 \mathrm{~min}$. each lasting 30 seconds or more. Repeat dose of $50 \mathrm{mg}$ tramadol or 15 mg pentazocine was injected intramuscular after 4 hours except in case where the women had reached the end of $1^{\text {st }}$ stage or entered $2^{\text {nd }}$ stage of labour. The following points were noted.

Time taken for onset of analgesic action was noted by verbal rating score. All resuscitative measures for mother and baby were kept ready. Vital parameter, foetal heart rate and progress of labour were checked repeatedly. Mode of delivery was noted, Apgar score of every infant was noted at 1 and $5 \mathrm{~min}$. Any complication or emergency reactions in both groups were noted.

\section{Observation}

Both the groups were comparable in age, parity, socioeconomic status and locality of patients.

Among both groups $50 \%$ patients were primigravida while $50 \%$ were multigravida. Mean age of patients in tramadol group was 25 years, while in pentazocine group it was 24.63 years. Maximum patients were of low socioeconomic status and from rural locality.

Mean gestational age was 38.13 weeks in Tramadol and 38.00 weeks in pentazocine group.
By giving I/M tramadol $80 \%$ cases responded, response was excellent in $23.33 \%$ cases and average in $56.67 \%$ cases while in pentazocine group pain relief was observed in only $60 \%$ of cases with excellent pain relief in only $6.67 \%$ cases (Table 1 ).

Mean onset of analgesia was early in Tramadol group (7.40 $\mathrm{min})$ in comparison to pentazocine group (15.60 min). However mean duration of analgesia was slightly more with pentazocine group $(2.67 \mathrm{hrs}$.) in comparison to tramadol (2.13 hrs.) (Table 2).

On correlating degree of pain with different physical factors, it was seen that in both the groups pain relief was maximum with 20-25 yrs. Age group, multigravida, stable personality, low socioeconomic status and rural locality.

Tramadol analgesia causes no appreciable changes in maternal pulse rate and blood pressure while with pentazocine mean pulse rate was significantly increased $1 \mathrm{hr}$. after giving injection $(9.80 / \mathrm{min})$ both systolic and diastolic blood pressure were increased and changes in systolic blood pressure were significant (Table 3).

Mean duration of $1^{\text {st }}$ stage of labour was more in pentazocine group $(9.13 \mathrm{hrs})$ in comparison to tramadol group (8.90 hrs). Similarly mean duration of IInd stage was more in pentazocine group, while mean duration of IIIrd stage was less in pentazocine group (8.20 $\mathrm{min})$ in comparison to tramadol group (9.03 $\mathrm{min}$ ) (Table 4).

Table 1: Degree of pain relief in tramadol and pentazocine groups.

\begin{tabular}{|c|c|c|c|c|}
\hline \multirow[t]{2}{*}{$\begin{array}{l}\text { Degree of } \\
\text { pain relief }\end{array}$} & \multicolumn{2}{|c|}{$\begin{array}{l}\text { Tramadol } \\
\text { group }\end{array}$} & \multicolumn{2}{|c|}{$\begin{array}{l}\text { Pentazocine } \\
\text { group }\end{array}$} \\
\hline & No. & $\%$ & No. & $\%$ \\
\hline Poor (score I) & 06 & 20 & 12 & 40 \\
\hline $\begin{array}{l}\text { Average } \\
\text { (score II ) }\end{array}$ & 17 & 56.67 & 16 & 53.33 \\
\hline $\begin{array}{l}\text { Excellent } \\
\text { (score III ) }\end{array}$ & 07 & 23.33 & 02 & 6.67 \\
\hline Mean & & 2.03 & & 1.67 \\
\hline S.D. & & 0.67 & & 0.60 \\
\hline $\mathrm{T}$ value & 2.211 & $\mathrm{p}<0.05$ & & \\
\hline
\end{tabular}

Table 2: Onset and duration of analgesia.

\begin{tabular}{|l|lllll|}
\hline Analgesia & & Tramadol group & Pentazocine group & t & $p$ \\
\hline Onset & Mean & 7.40 & 15.60 & 7.918 & $<0.01$ \\
\hline (min) & SD & 1.77 & 4.66 & & \\
\hline Duration & Mean & 2.13 & 2.67 & 3.431 & $<0.05$ \\
\hline (hrs) & SD & 0.58 & 0.38 & & \\
\hline
\end{tabular}


Table 3: Changes in maternal pulse rate, systolic and diastolic blood pressure.

\begin{tabular}{|lllllll|}
\hline $\begin{array}{l}\text { Changes } \mathbf{~ h r} \text { after } \\
\text { injection }\end{array}$ & $\begin{array}{l}\text { Tramadol } \\
\text { group Mean }\end{array}$ & $\begin{array}{l}\text { Tramadol } \\
\text { group SD }\end{array}$ & $\begin{array}{l}\text { Pentazocine } \\
\text { group Mean }\end{array}$ & $\begin{array}{l}\text { Pentazocine } \\
\text { group SD }\end{array}$ & $\mathbf{t}$ & $p$ \\
\hline Pulse rate /min & 0.47 & 3.04 & 9.80 & 2.75 & 12.466 & $<0.01$ \\
\hline Systolic B.P./min & 1.30 & 4.52 & 9.53 & 4.49 & 5.019 & $<0.01$ \\
\hline Diastolic B.P./min & 0.53 & 4.56 & 5.37 & 5.03 & 3.905 & $<0.05$ \\
\hline
\end{tabular}

Table 4: Duration of stages of labour in tramadol and pentazocine groups.

\begin{tabular}{|lllllll|}
\hline \multirow{2}{*}{ Groups } & \multicolumn{2}{l}{ Stage I (hrs ) } & \multicolumn{2}{c|}{ Stage II (hrs ) } & \multicolumn{2}{c|}{ Stage III (min ) } \\
\cline { 2 - 8 } & Mean & SD & Mean & SD & Mean & SD \\
\hline Tramadol group & 8.90 & 3.71 & 0.68 & 0.52 & 9.03 & 4.86 \\
\hline Pentazocine group & 9.13 & 3.41 & 0.73 & 0.69 & 7.20 & 3.28 \\
\hline $\mathrm{t}$ & & 0.250 & 0.317 & 0.317 & 1.710 & \\
\hline$p$ & $>0.05$ & & $>0.05$ & & $>0.05$ & \\
\hline
\end{tabular}

Table 5: Mode of delivery in different groups.

\begin{tabular}{|llll|l|}
\hline $\begin{array}{l}\text { Mode of } \\
\text { delivery }\end{array}$ & \multicolumn{2}{l}{$\begin{array}{l}\text { Tramadol } \\
\text { group }\end{array}$} & \multicolumn{3}{l|}{$\begin{array}{l}\text { Pentazocine } \\
\text { group }\end{array}$} \\
\cline { 2 - 5 } & No. & $\%$ & No. & $\%$ \\
\hline Normal & 26 & 86.66 & 24 & 80.00 \\
\hline Instrumental & 02 & 6.67 & 02 & 6.67 \\
\hline $\begin{array}{l}\text { Caesarean } \\
\text { section }\end{array}$ & 02 & 6.67 & 04 & 13.33 \\
\hline
\end{tabular}

Table 6: Mean apgar score of neonates.

\begin{tabular}{|llll|l|}
\hline \multirow{2}{*}{ Time } & \multicolumn{2}{l}{$\begin{array}{l}\text { Tramadol } \\
\text { group }\end{array}$} & \multicolumn{2}{l|}{$\begin{array}{l}\text { Pentazocine } \\
\text { group }\end{array}$} \\
\cline { 2 - 5 } & Mean & SD & Mean & SD \\
\hline At 1 min. & 7.63 & 1.67 & 7.73 & 1.26 \\
\hline At 5 min. & 9.60 & 0.60 & 9.33 & 0.91 \\
\hline
\end{tabular}

Table 7: Side effects in tramadol and pentazocine group.

\begin{tabular}{|lllll|}
\hline \multirow{2}{*}{ Side effects } & \multicolumn{2}{l}{$\begin{array}{l}\text { Tramadol } \\
\text { group }\end{array}$} & \multicolumn{2}{l|}{$\begin{array}{l}\text { Pentazocine } \\
\text { group }\end{array}$} \\
\cline { 2 - 5 } & No. & $\%$ & No. & $\%$ \\
\hline Nausea & 2 & 6.67 & 2 & 6.67 \\
\hline Vomiting & 1 & 3.33 & 2 & 6.67 \\
\hline Drowsiness & 1 & 3.33 & 4 & 13.67 \\
\hline Tachycardia & 2 & 6.67 & 7 & 23.33 \\
\hline Increase in B.P. & 2 & 6.67 & 10 & 33.33 \\
\hline $\begin{array}{l}\text { Post partum } \\
\text { Haemorrhage }\end{array}$ & 2 & 6.67 & 2 & 6.67 \\
\hline Foetal distress & 1 & 3.33 & 3 & 10 \\
\hline
\end{tabular}

Normal delivery occurred in $86.66 \%$ cases of tramadol group in comparison to $80 \%$ cases of pentazocine group. Operative interference was more in pentazocine group (20\% cases) while in tramadol group it was needed in only $13.34 \%$ cases (Table 5 ).
Mean apgar score was more in tramadol group in comparison to pentazocine group. It was7.93 and 7.73 at $1 \mathrm{~min}$. and 9.60 and 9.33 at $5 \mathrm{~min}$. in tramadol group and pentazocine groups respectively (Table 6).

Side effect were more in pentazocine group in form of nausea, vomiting (13.34\%), tachycardia (23.33\%) increase in blood pressure $(38.33 \%)$ and feotal distress (10\% cases ) (Table 7).

\section{DISCUSSION}

Prasertsawat et al (1986) observed that $100 \mathrm{mg}$ tramadol gives satisfactory to good effect in $78 \%$ patients. ${ }^{9}$ However, Suvonnakote et al (1986) reported that 59\% patients did not obtain adequate analgesia with Tramadol. ${ }^{11}$

Nawani et al (1996) observed excellent to average pain relief with tramadol in $80 \%$ cases while Sarkar and Mukhopadhyay (1997) observed satisfactory pain relief in $13 \%$ and average pain relief in $85 \%$ cases. ${ }^{8,10}$

Mean onset of analgesia was $7.40 \mathrm{~min}$. and effect lasted for $2.13 \mathrm{hrs}$. in present study. While Husslein et al (1987) concluded that distinct analgesic effect was observed after $10 \mathrm{~min}$. and lasted for $2 \mathrm{hrs}^{4}$

Duration of different stages of labour was not increased after use of tramadol while in pentazocine group $1^{\text {st }}$ stage of labour was significantly prolonged. Bitsch et al (1980) also observed that tramadol has no effect on duration and intensity of uterine contractions and on duration of different stages of labour. ${ }^{3}$

Maternal and foetal side effects were very few in tramadol group in comparison to pentazocine group.

In present study, we have found that tramadol is superior in all aspects, onset was earlier, degree of pain relief was 
better and there was no danger of maternal and foetal neonatal respiratory depression. Operative interference and complications were more in pentazocine group. The only advantage of pentazocine was that mean duration of analgesia was more with pentazocine $(2.67 \mathrm{hrs})$ in comparison to tramadol (2.13 hrs) although it was not significant.

All these findings confirm the superiority of tramadol over pentazocine for labour analgesia.

Funding: No funding sources

Competing interests: None declared

Ethical approval: The study was approved by the Institutional Ethics Committee

\section{REFERENCES}

1. Bajaj P, Meena R, Prasad P, Intravenous tramadol for labor analgesia. Indian Pract 1997;50:1051-4.

2. Bitsch M, Emmrich J, Hary J, Lippach G, Rindt W. Geburtshilfliche analgesie mit tramadol. Fortschritte der Medizin 1980;16:632-4.

3. Husslein P, Kubista E, Egarter C. Obstetrical Analgesia with tramadol-results of a prospective randomized comparative study with pethidine. Z Geburtshilfe Perinatol 1987;191:234-7.

4. Jain S, Arya VK, Gopalan S, et al. Analgesic efficacy of intramuscular opioids versus epidural analgesia in labor. Int J Gynecol Obstet 2003;83:1927.

5. Keskin HL, Keskin EA, Avsar AF, et al. Pethidine versus tramadol for pain relief during labor. Int $\mathbf{J}$ Gynaecol Obstet 2003;82:11-6.
6. Li E, Weng L. Influence of dihydroetorphine hydrochloride and tramadol on labour pain and umbilical blood gas. Zhonghua Fu Chan Ke Za Zhi 1995;30:345-8.

7. Nawani M, Sharma S, Nawani DP, et al. U.P. Chapter of obstetrics and gynecology, volume II, 1996 Feb-Mar:41.

8. Prasertsawat PO, Herabutya Y, Chaturachinda K. Obstetrics analgesia. Current Therapeutic Research 1986;40:1022-8.

9. Sarkar B, Mukhopadhyay AK. Tramadol hydrochloride in dysfunctional labour - A clinical trial. J Obstet Gynecol India 1997;47:42-8.

10. Suvonnakote T, Thitadilok W, Atisook R. Pain relief during labour. J Med Assoc Thailand 1986;69:576-80.

11. Viegas OA, Khaw B, Ratnam SS, Eue J. Tramadol in labour pain in primiparous patients-A prospective comparative clinical trial. Obstet Gynecol Biol 1993;49:131-5.

DOI: $10.5455 / 2320-1770 . \mathrm{ijr} \operatorname{cog} 20130615$

Cite this article as: Chandnani K, Sainee HB. Pain relief in labour: tramadol versus pentazocine. Int $\mathrm{J}$ Reprod Contracept Obstet Gynecol 2013;2:186-9. 